\title{
Geological Survey and Museum
}

\section{Ceremonial Opening of New Museum}

$\mathrm{O}^{\mathrm{s}}$ N Wednesday, July 3, H.R.H. The Duke of York performed the opening ceremony of the new Museum of Practical Geology in Exhibition Road, South Kensington. A description of the building and its principal exhibits appeared in NATURE of June 29 (p. 1060).

His Royal Highness was received at the door of the Museum by the Mayor of Kensington. The official party that accompanied the Duke to the platform were: The Right Hon. W. G. A. OrmsbyGore, First Commissioner of H.M. Office of Works, Lord Rutherford, chairman of the Advisory Council for Scientific and Industrial Research, Sir Patrick Duff, secretary of H.M. Office of Works, Mr. J. H. Markham, the architect, Sir Frank Smith, secretary of the Department of Scientific and Industrial Research, Sir John Flett, the director of the Geological Survey, and Dr. W. F. P. McLintock, the curator of the Museum.

Mr. Ormsby-Gore, in inviting His Royal Highness to declare the Museum open to the public, said that the Geological Survey of Great Britain is the oldest national geological survey in the world. It was instituted for the purpose of preparing copies of the Ordnance Survey maps geologically coloured so as to be of service to science and industry by providing an accurate representation of the geology of Great Britain. The Museum of Practical Geology developed out of the collection by the Survey of specimens of rocks, minerals and fossils, and was first opened to the public in 1841. It was soon found that the importance of the collection warranted the erection of a building designed to display the work of the Survey and the application of geology to the arts and industry, and in the year of the Great Exhibition the building in Jermyn Street was opened by the Prince Consort. The new Museum was commenced in 1929 and was substantially completed in 1933, when it was required for the World Monetary and Economic Conference. The cost of the building was some $£ 220,000$, and a lease of the Crown site of the old premises had been granted at a rent which considerably exceeded the interest on the capital sum expended on the new building.

The Duke of York said that the new building makes a notable and welcome addition to the great museums erected on the land provided for the encouragement of science, art and industry by the wise foresight of the Prince Consort. With the Science Museum on one side and the natural history section of the British Museum on the other, it provides a suite of scientific exhibits unequalled in any other country. In 1683 the Duke of York, later James II, opened the Ashmolean Museum at Oxford, which contained the first British geological collection. In 1835 , as a result of the work of Henry de la Beche, the Geological Survey was founded as the first official organisation of its kind. To-day there are more than 120 official geological surveys in different parts of the world, to many of which, and particularly those in other parts of the Empire, the Geological Survey of Great Britain has been a parent. He was glad to know that a large number of delegates from abroad had come to celebrate the centenary of the Survey.

The Museum was well filled with a large and representative gathering that included British, Colonial and foreign geologists who had been invited to participate in the ceremonies. The new Museum was much admired and it was generally acknowledged that no geological survey in the world has better offices, library and laboratories and a more satisfactory museum. Some of the directors of geological surveys took many notes of the organisation and arrangements of the exhibits, and they were particularly struck by the effort that has been made to attract the interest of the non-geological public.

On Wednesday evening, July 3, the Geological Society of London gave a reception to the foreign and Empire delegates in its rooms in Burlington House.

\section{Centenary of the Geological Survey}

On Thursday, July 4, at 11 a.m., a meeting was held in the hall of the Royal Geographical Society to celebrate the centenary of the Geological Survey of Great Britain. Lord Rutherford of Nelson occupied the chair, and was accompanied by Sir Frank Smith and Dr. T. F. Sibly, representing the Department of Scientific and Industrial Research and the Geological Survey Board.

In a brief introductory speech, Lord Rutherford commented on the great progress which the know. ledge of geology has made in the last hundred years and the distinguished part which British geologists have played in furthering the growth of the science. $\mathrm{He}$ cited the names of William Smith, Lyell, Sedgwick, Murchison, Darwin and others as founders of geology, and expressed his thanks to the foreign, Dominion and Colonial geologists who had accepted the invitation to assist in the celebration.

The overseas and British delegates then responded to their names and were presented to the chairman.

The list of delegates is much too long to be given in full as it contains more than two hundred names, of which 85 were from foreign countries. Mention, however, may be made of a few selected names. The Belgian delegation was very representative, including Prof. Renier (Brussels), Prof, Fourmarier (Liège), Profs. Halet, Legraye, Van Straelen and Thoreau. Prof. Robert represented the Geological Survey of the Belgian Congo. From France arrived Profs. de Margerie, Jacob (Paris), Léon Bertrand (Paris), Fallot (Nancy), Dubois (Strasburg), Roman (Lyon), Besairie (Madagascar), Bétier (Algeria), Legoux (French West Africa). The German delegation was led by Prof. von Seidlitz (Director, Geological Survey of Prussia) and included Profs. Stille, Cloos, Hirmer, Angenheister and Schmidtgen. Among others present were Madsen (Denmark), Gavelin and von Eckermann (Stockholm), Laitakari (Helsingfors), Kettner (Prague), Crema (Italy), Loczy de Locz (Hungary), Morozewicz (Poland), Royo y Gomez (Madrid). The Swiss representatives were Profs. Lugeon, Buxtorf and Staub, and much interest was taken in the two Russian delegates, Prof. Ferodowsky (Moscow) and Prof. Karpinsky, the president of the 
Academy of Sciences in Leningrad, who is in his ninetieth year and had flown to London, accompanied by his daughter. From the United States there came Dr. Day of the Geophysical Laboratory of the Carnegie Institution of Washington; Dr. Matthews, Johns Hopkins University, Baltimore; Profs. Rice (Harvard), Moore (Kansas), Marquis (Washington), Leith (Wisconsin), Anderson (Stanford), Leuschner (Berkeley). From Canada, Profs. Coleman (Toronto), Adams (Montreal), Atkinson (Saskatoon). Among other distinguished Empire geologists present were Grabham (Sudan), Haughton (Pretoria), Richards (Queensland), Kitson (Victoria), Pascoe (India), Lightfoot (Southern Rhodesia), Seymour (Dublin), Mellor (Johannesburg), Scrivenor (Malaya) and Raeburn (Nigeria).

Thereafter, Sir John Flett, director of the Geological Survey and Museum, gave an address on the history and functions of the Geological Survey. He outlined briefly the state of geological science in the year 1835 when the Survey was founded, and remarked on the brilliant assemblage of geologists then living in London, among whom were Buckland, Murchison, Sedgwick, Lyell, Greenough, Fitton, MacCulloch and De la Beche. Much interest was being taken in geological maps. William Smith's famous map had appeared in 1815. Greenough's map was issued in 1820. A desire for still better maps was strongly felt and with the support of Colby, director of the Ordnance Survey, a deputation of prominent members of the Geological Society of London represented to the Prime Minister the value of geologically coloured maps on the scale of one-inch to a mile. Consent was obtained and the work was entrusted to Henry de la Beche. The work began in Devon and Cornwall, spread thence to Wales and eastwards to the London district and the Midlands. By 1860 it had reached the Lancashire and Yorkshire coalfields, and in 1883 the original survey of England and Wales was finished. Simultaneously, the Geological Surveys of Ireland and Scotland had been active both in field work and in publication. De la Beche was remarkably successful in enlisting able and enthusiastic assistants, among whom Ramsay, Aveline, Selwyn, Logan and Jukes did imperishable work.

De la Beche died in 1855 and was succeeded by Sir Roderick Murchison, who was an active and efficient director. He was followed by Sir Andrew Ramsay, equally skilled in the field and with the pen, who had been De la Beche's loyal lieutenant. Sir Archibald Geikie in turn held control until the end of last century. What is known as the 'Old Series' of hand-coloured geological maps was essentially the product of the labours of the staff under these leaders. In 1901 Sir Jethro Teall took up the reins, followed by Sir Aubrey Strahan. Many improvements were made in all departments of the service and the present type of colour-printed maps was introduced.

At first under the Board of Ordnance, then under the Woods, Works and Forests, then under the Board of Trade and the Science and Art Department, soon transferred to the Board of Education, and since 1919 under the newly constituted Department of Scientific and Industrial Research, the Geological Survey and Museum has pursued an even course.

De la Beche started to exhibit geological specimens, maps, models and mining apparatus in rooms in Craig's Court about 1837. The old Museum of Practical Geology in Jermyn Street was opened by the Prince Consort in 1851. It is now in process of demolition. This furnished an opportunity to realise De la Beche's ambition to found a School of Mines resembling the famous institutions of the Continent, and in this also he was successful. After preliminary vicissitudes the School achieved a great reputation and many famous names are found in the lists of its staff. Forbes, Huxley, Playfair, Frankland, Warington Smyth, Percy, Stokes, Tyndall, Le Neve Foster, were among the professors. The men who were privileged to study under them are justly proud of their School and its great traditions.

The School of Mines outgrew its accommodation at Jermyn Street and was transferred by stages to South Kensington, where now it occupies commodious buildings adjacent to the Science Museum and the Geological Survey and Museum.

The practical applications of geology were never absent from the mind of De la Beche. He established a Mining Record Office for collecting statistics of output and plans of mines. His chemists also attacked many practical problems, such as British iron ores and steam coals for the Navy. Science was for him not a lonely virgin but the fruitful partner of industry: Could he return to-day and see how widely his influence has spread, even he might be astonished. The old collections of Jermyn Street have fertilised the Science Museum, Bethnal Green Museum, Science Library, School of Mines, Mines Department, Imperial College and the Victoria and Albert Museum. All of these contain material that can be traced to his assiduous and enterprising activities. His successors, though their energies are less widely dispersed, maintain close connexion with practical problems. Water-supply, engineering, fuel research, agriculture, mining, architecture, transport, all call for geological information and receive their due share of attention.

At the conclusion of the director's address, the chairman called upon some of the delegates to speak. Prof. Coleman (Toronto), Prof. Matthews (Baltimore), Prof. de Margerie (Paris), Prof. von Seidlitz (Berlin) and Prof. W. W. Watts (London) in turn expressed their appreciation of the work of the Geological Survey, and the services it has rendered to geological science and to the prosperity of Great Britain.

In the evening at 7 o'clock the staff of the Geological Survey and the members of the Dining Club of the Geological Society entertained the Overseas delegates and their wives to dinner at the Rembrandt Hotel. The Company numbered 220 and only two speeches were delivered. Sir John Flett as chairman proposed the toast of the guests, which was responded to by Dr. A. L. Day, director of the Geophysical Laboratory of the Carnegie Institution of Washington and vice-president of the National Academy of Sciences of the United States.

Thereafter the company proceeded to Lancaster House, where a Government reception was held. The guests, numbering more than a thousand, were received by the First Commissioner of H.M. Office of Works and Lady Beatrice Ormsby-Gore.

On Friday, July 5, a series of excursions to districts of geological interest, specially conducted by officers of the Geological Survey for the benefit of those who attended the celebrations, left London. The selected localities are Edinburgh and the Forth Valley, Bristol and South Wales, and the Isle of Wight. Each excursion is to last for a week, and descriptive programmes and itineraries have been specially prepared. 